\title{
Multivariate analysis of the 3D composites based on nickel microparticles
}

DOI: 10.35530/IT.071.05.1772

RALUCA MARIA AILENI

IRINA MARIANA SANDULACHE

LAURA CHIRIAC

SILVIAALBICI

VALERIA NEAGU

LILIANA RADUCU

\section{ABSTRACT - REZUMAT}

\section{Multivariate analysis of the 3D composites based on nickel microparticles}

This paper presents multivariate analyses of the experimental parameters obtained in the scientific experiments on eight sample fabrics of $100 \%$ cotton with electrically conductive properties and electromagnetic achieved through traditional treatments such as padding with antistatic agents, and direct printing or scraping with a polymeric paste based on nickel (Ni). Textile printing was obtained using polymers such as polyethylene glycol (PEG), polyvinyl alcohol (PVA), polyacrylate, ammonium salt, carboxylic acid Copolymer polyester, and Ni microparticles. For the eight samples that have been analyzed, the morphology of the surfaces using SEM (scanning electron microscope) with magnification 2000-8000x and electronic magnification microscopy with $4 x$, assessed the resistance to wet rubbing and dry the resistance of the surface after treatment in the solution of alkaline and acid sweat. Also, the samples above referred have been analyzed by spectrophotometry to evaluate the transmittance, and reflectance of the electromagnetic waves. It can specify that after treatments in acid or alkaline sweat solutions, the resistance of the surface has decreased by $10^{3}-10^{5}$. It has been observed that for samples treated with acid or alkaline sweat, the reflectance was increased in comparison with the reflectance obtained for the original samples. The multivariate analysis provided refers to the study of some physic-chemical and optical parameters, of the samples collected, such as thickness, $\mathrm{pH}$, reflectance, and transmittance.

Keywords: composites, electroconductive, textile, resistance, nickel, $3 D$

\section{Analiza multivariată a compozitelor 3D pe bază de microparticule de nichel}

În această lucrare sunt prezentate analize multivariate pentru parametrii experimentali obţinuţi în cadrul experimentelor ştiinţifice pentru opt probe de material textil din 100\% bumbac, având proprietăţi electroconductive şi electromagnetice obţinute prin tratamente clasice, cum ar fi fulardarea cu agenţi antistatici, sau imprimarea directă ori raclarea unei paste polimerice pe bază de nichel (Ni). Imprimarea textilă a fost obţinută prin utilizarea unor polimeri cum ar fi polietilen glicol (PEG), alcool polivinilic (PVA), poliacrilaţi, sare de amoniu, acid carboxilic copolimer poliester, cu conţinut de microparticule de Ni. Pentru cele 8 probe a fost analizată morfologia suprafeţelor utilizând SEM (microscopul de scanare electronică) cu gradul de magnifiere 2000-8000x şi microscopul electronic cu grad de mărire 4x, determinându-se și rezistenţa la frecare umedă şi uscată, rezistenţa de suprafaţă după tratamente în soluţii de transpiraţie acidă şi alcalină. De asemenea, probele mai sus menţionate au fost analizate prin spectrofotometrie pentru evaluarea transmitanţei şi reflectanţei undelor electromagnetice. Se poate specifica că rezistenţa de suprafaţă în cazul probelor tratate cu soluţii de transpiraţie acidă sau alcalină a fost redusă cu $10^{3}-10^{5}$. S-a observat că pentru probele tratate cu soluţii de transpiraţie alcalină sau acidă reflectanţa a crescut în comparaţie cu reflectanţa obţinută pentru probele iniţiale (martor). Analiza multivariată se referă la studierea unor parametri fizico-chimici şi optici, obţinuţi pentru probele analizate, cum ar fi grosimea materialului, $\mathrm{pH}$, reflectanţa şi transmitanţa.

Cuvinte-cheie: compozite, electroconductiv, textile, rezistenţă, nichel, 3D

\section{INTRODUCTION}

The multivariate analysis represents the statistical study of experiments in which dependent variables from measurements and the relationship among multivariate measures [1] and their structure analyzed to understand the experiments. Moreover, the multiple responses to a test performed on the samples may offer valuable information concerning toxicity, permanent surface resistance, or temporary character. Also, this involves measuring the strength of relationships among various measurements (e.q. resistance to alkaline/acid sweat or to wet/dry rubbing).

Development of the products such as sensors, actuators, batteries, the based metal coating must be defined in some aspects concerning the toxicity of the metal used and the usability in contact or not with the skin. Concerning nickel, at the European level, it is the Nickel Directive EN 1811 [2] regulating the use of nickel $(\mathrm{Ni})$ in jewelry and other products that come into contact with the skin because of nickel allergy is a common cause of contact dermatitis. However, $\mathrm{Ni}$ is used in many everyday items, such as coins, zippers, cell phones, and eyeglass frames, and some of these items are used in the textile industry. The European Nickel Directive EN 1811 is the internationally recognized test method to determine the rate of nickel release from jewelry, spectacle frames, and other items. In the scientific literature are presented 
several electrochemical tests (potential vs. time, potentiodynamic corrosion/polarization tests [3-5]) and the synthetic sweat tests.

The standard, EN 1811:2011 the amendment no. $1 / 2015$ concerning testing to the nickel [6] release allow a level of $0.11-9.35 \mu \mathrm{g} / \mathrm{cm}^{2} /$ week for post assemblies and body piercing and $0.28-0.88 \mu \mathrm{g} / \mathrm{cm}^{2} /$ week for components in direct and prolonged contact with the skin. Several papers state that nickel migration can be identified by artificial sweat $[7,8]$ and, in this way, can be evaluated the exposure to trace elements through clothes $[9,10]$.

\section{EXPERIMENTAL PART}

In the experiments below presented, we developed eight models using $100 \%$ cotton fabric to obtain the surface with electroconductive properties. The objective was to get materials with electro-conductive properties using standard technologies (printing, scrapping, and padding) and nickel (Ni) microparticles. Preliminary treatments on the fabrics have been performed to obtain the antistatic (Avistat $3 \mathrm{P}$, Arristan AIR, and Aristan CPU), hydrophilic (Tubicoat 41, and Tubifast) and hydrophobic (NUVA) effect. The conductive paste based on water, Tubicoat binder, Tubivis DL 650, and micro/nanoparticles of nickel $(<50 \mu \mathrm{m})$ was dried on the fabric surface at a temperature of $120^{\circ} \mathrm{C}$ for two minutes and condensation at a temperature of $140^{\circ} \mathrm{C}$, for 3 minutes. For comparison, the printing with a conductive paste based on nickel performed on one side of the fabric and both sides of the fabric surface. Table 1 presents the surface analyses by electronic microscope with 4x magnification and thickness of the materials analyzed. Table 2 presents the SEM (Scanning electron microscope) analysis of the samples untreated (sample no. 0) and

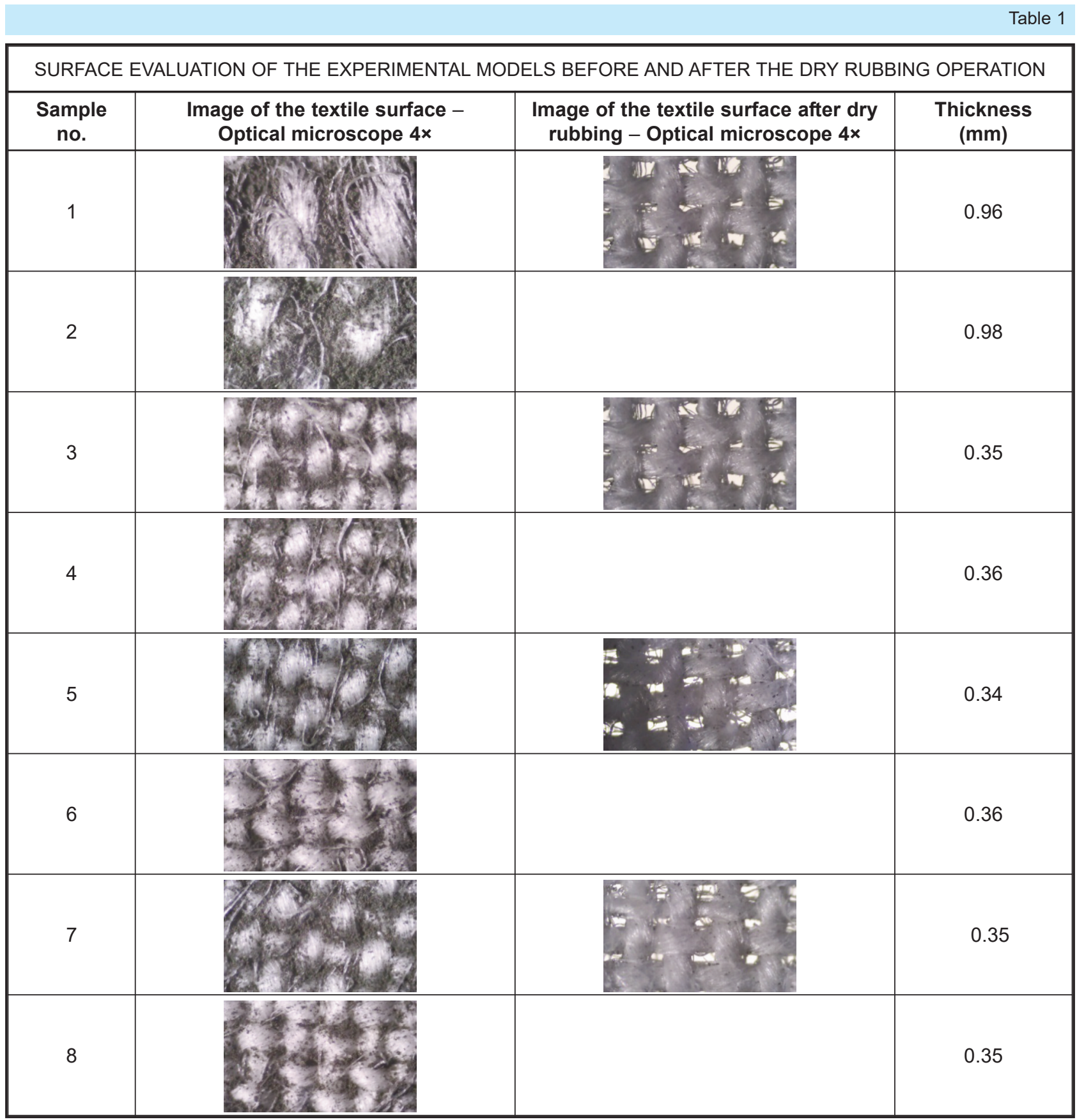




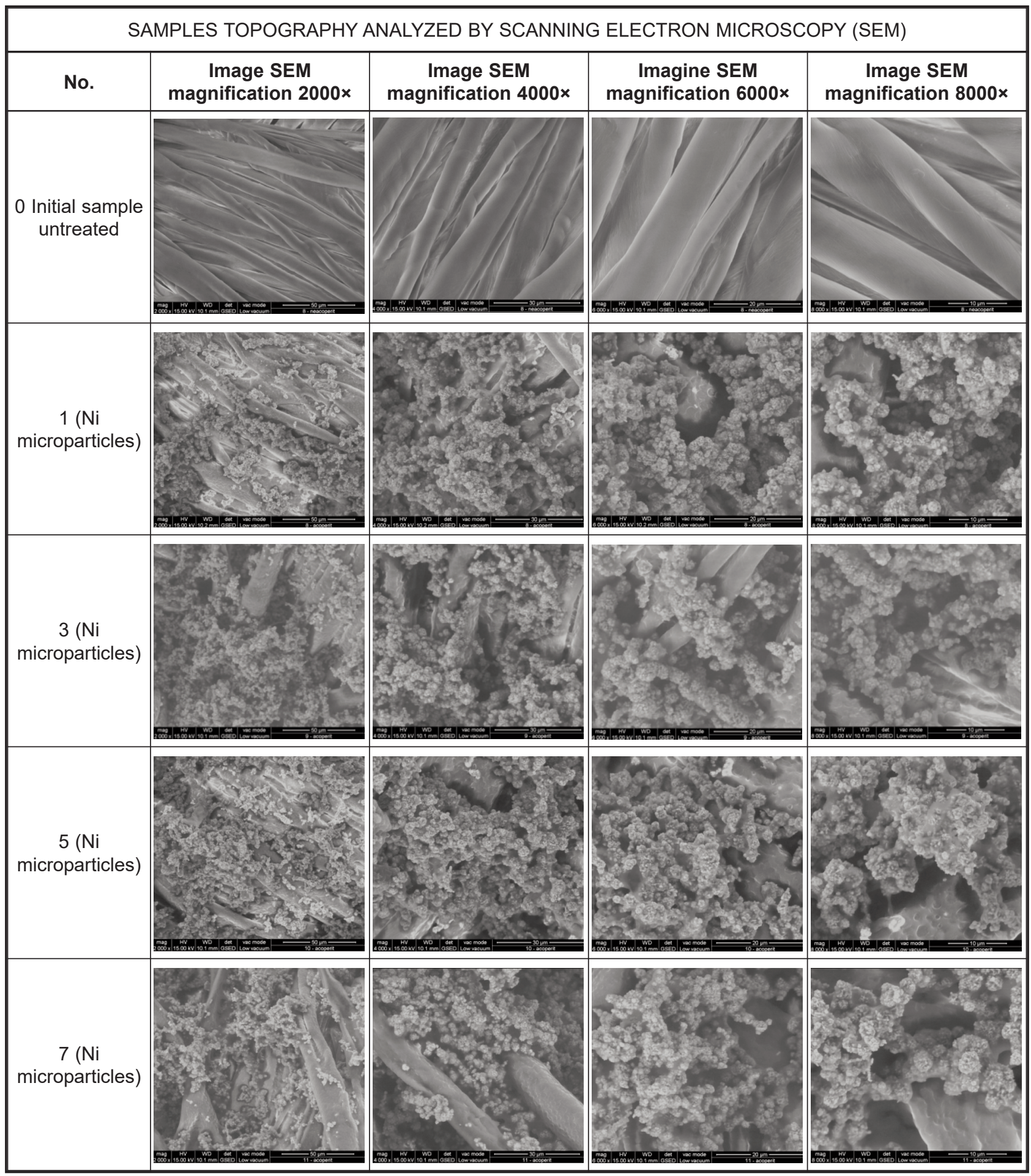

treated with conductive paste (samples no. 1, 3, 5 and 7 ). In table 2 the micro/nanoparticles deposited can be observed very well and also it can be seen as a clusterization tendency of the micro/nanoparticles. Nickel is a common cause of allergic contact dermatitis and can be found in many everyday items, such as coins, zippers, cellphones, and eyeglass frames, not only in sensor components. Taking into account these aspects, we decided to provide some preliminary tests to evaluate if the nickel microparticles from polymeric paste can migrate or no on other textile layers. To assess the resistance of the conductive coating of textiles to wet and dry rubbing, we deve- loped an experiment that consists of rubbing the coated fabric with a dry tissue and with a wet material (figure 1). The final samples (figure 1) were optically appreciated, using greyscale and notes from 1 to 5 (table 3).

For the eight experimental models there were determined in the laboratory the resistance to acid and alkaline sweat for 4 hours at a temperature of $37^{\circ} \mathrm{C}$, dry $\left(R_{d}-\right.$ figure $\left.1, a\right)$ and wet $\left(R_{w}-\right.$ figure $\left.1, b\right)$ rubbing resistance (wetting 98\%, the frictional force $9 \mathrm{~N}$ ) parallel to the warp direction (table 3 ), $\mathrm{pH}$ following PS-C-02, SR EN ISO 3071/2006 and surface resistance before sweat treatments $\left(R_{\mathrm{si}}\right)$, surface resistance 


\begin{tabular}{|c|c|c|c|c|c|c|c|c|c|c|c|}
\hline \multicolumn{12}{|c|}{$\begin{array}{c}\text { LABORATORY TESTS - RESISTANCE TO ACID AND ALKALINE SWEAT, RESISTANCE WET AND DRY RUBBING, } \\
\text { RESPECTIVE THE REPORT [R/T] }\end{array}$} \\
\hline Sample & $\begin{array}{l}\text { Acid } \\
\text { sweat }\end{array}$ & $\begin{array}{c}\text { Alkaline } \\
\text { sweat }\end{array}$ & $\mathbf{R}_{\mathrm{d}}$ & $\mathbf{R}_{\mathrm{w}}$ & $\begin{array}{l}R_{s i} \\
(\Omega)\end{array}$ & $\begin{array}{c}\mathbf{R}_{\text {SAL }} \\
(\Omega)\end{array}$ & $\begin{array}{c}\mathrm{R}_{\text {SAC }} \\
(\Omega)\end{array}$ & $\mathrm{pH}_{\text {initial }}$ & $\mathrm{pH}_{\text {samples }}$ & {$[R / T]$} & $\begin{array}{c}\delta \\
(\mathrm{mm})\end{array}$ \\
\hline 1 & $4-5$ & $4-5$ & 4 & $2-3$ & $10^{12}$ & $10^{8}$ & $10^{9}$ & 8.3 & 8.6 & 18.71 & 0.96 \\
\hline 2 & $4-5$ & $4-5$ & - & - & $10^{12}$ & $10^{8}$ & $10^{7}$ & 7.09 & 8.6 & 14.06 & 0.98 \\
\hline 3 & $4-5$ & $4-5$ & 3 & $1-2$ & $10^{12}$ & $10^{8}$ & $10^{9}$ & 6.546 & 6.231 & 16.93 & 0.35 \\
\hline 4 & $4-5$ & $4-5$ & - & - & $10^{12}$ & $10^{8}$ & $10^{9}$ & 6.502 & 6.203 & 22.42 & 0.36 \\
\hline 5 & $4-5$ & $4-5$ & 2 & $1-2$ & $10^{12}$ & $10^{8}$ & $10^{8}$ & 6.5 & 6.6 & 16.73 & 0.34 \\
\hline 6 & $4-5$ & $4-5$ & - & - & $10^{12}$ & $10^{8}$ & $10^{8}$ & 6.5 & 6.6 & 19.40 & 0.36 \\
\hline 7 & $4-5$ & $4-5$ & $3-4$ & 2 & $10^{12}$ & $10^{8}$ & $10^{8}$ & 6.5 & 7.2 & 22.83 & 0.35 \\
\hline 8 & $4-5$ & $4-5$ & - & - & $10^{12}$ & $10^{7}$ & $10^{8}$ & 6.5 & 6.98 & 20.23 & 0.36 \\
\hline
\end{tabular}
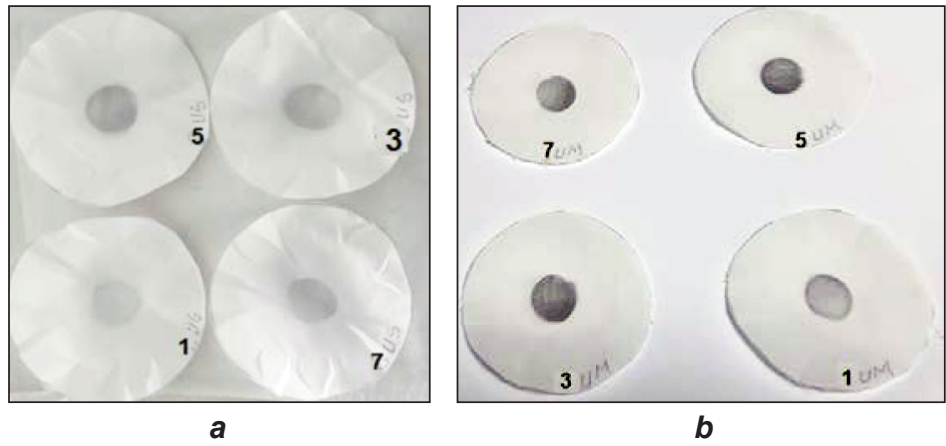

Fig. 1. Resistance to dry and wet rubbing: $a$ - dry rubbing; $b$ - wet rubbing

after alkaline sweat treatment $\left(R_{\mathrm{SAL}}\right)$, surface resistance after acid sweat treatment $\left(\mathrm{R}_{\mathrm{SAC}}\right)$. From table 3 it can be observed a reduction to $10^{4}-10^{5} \Omega$ of surface resistance after alkaline sweat treatment, respective with $10^{3}-10^{5} \Omega$ after acid sweat treatment, and the insulator fabric becomes a material with excellent antistatic properties. This preliminary evaluation will help us in future support decisions to decide on which type of electrodes (skin contact or not) can be used in this fabric based on nickel coating.

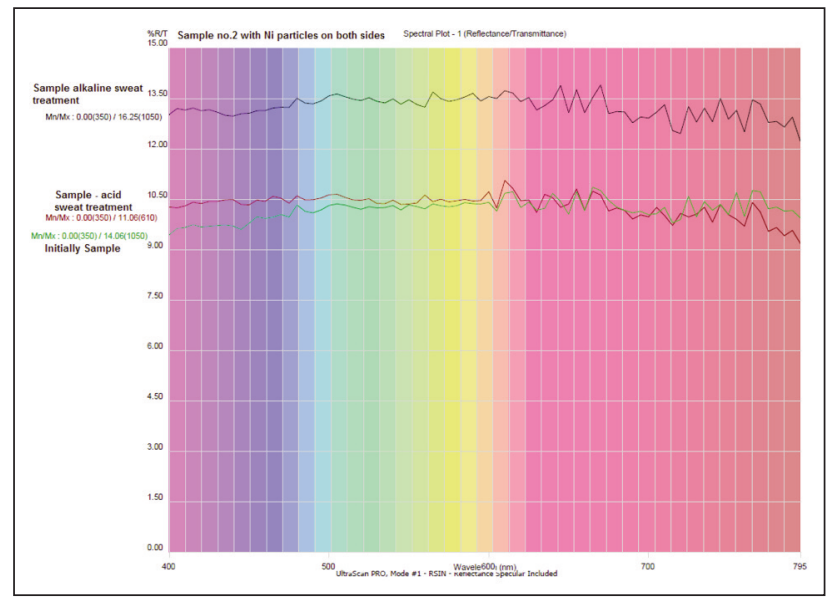

Fig. 2. Spectral plot sample no. 2 (both sides coating)
Spectrophotometry is the method that measures the degree of absorption of light by a chemical substance by measuring the intensity of the light as a beam of light is directed through the chemical substance. The spectrophotometer Hunterlab UltraScan PRO is used for research and quality control for solid opaque, clear, transparent liquid films. The UltraScan PRO measures with precision the reflectance and transmittance, noise in the transmission, and color of the reflected and transmitted.

Samples no. 2 and no. 8, were tested using a spectrophotometer UltraScan Pro to see if occur some modification in light reflectance (equation 1)/transmission (equation 2) $[R / T]$ and light absorption (equation 3). Figure 2 presents the spectral plot for sample no. 2 and figure 3 presents spectral plot [R/T] for sample no. 8:

$$
T=\mathrm{e}^{-\tau}=10^{-A}
$$

where $T$ is the optical depth and $A-$ the absorbance.

$$
q(y)=G_{r}(y) / G_{i}(y)
$$

where $G_{r}$ is the reflected radiation and $G_{i}$ - the incident radiation.

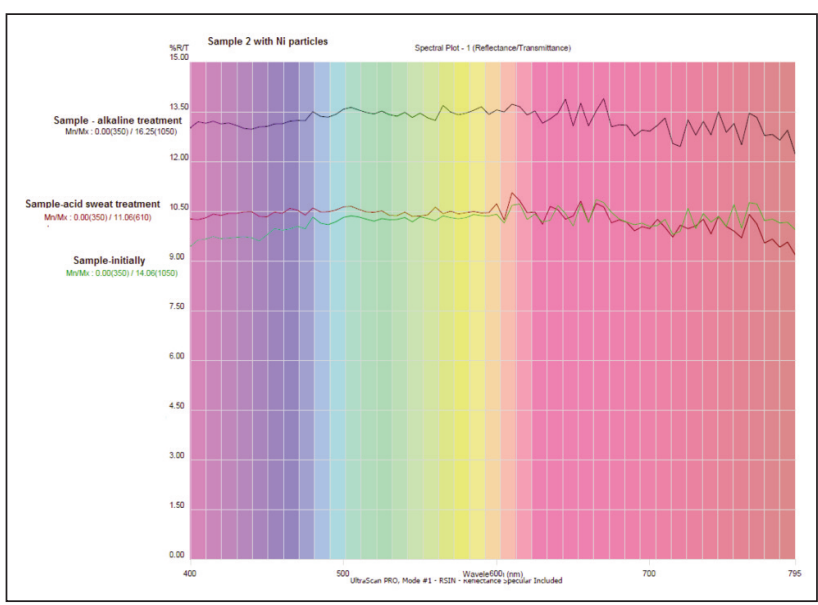

Fig. 3. Spectral plot sample no. 2 one (one side coating) 


\section{RESULTS AND DISCUSSIONS}

The multivariate technique in MATLAB analyzed the experimental data, and we developed the mathematical model (equation 3) based on experimental data obtained for reflectance/transmittance ([R/T]), $\mathrm{pH}$ and textile material thickness $(\delta)$. Figure 4 presents the $3 \mathrm{D}$ representation of the reflectance/ transmittance $([R / T])$ of the samples obtained by printing method in the function of the thickness $(\delta)$ and $\mathrm{pH}$ using MATLAB software and multivariate analysis of the reflectance/ transmittance $([R / T])$ according to the thickness $(\delta)$ and $\mathrm{pH}$ :

$$
\begin{aligned}
z=f(x, y) \Leftrightarrow z & =a+b * x * y+c * x^{7} * y+d * x^{6} * y^{6}+ \\
& +e * y^{7} x^{5}+f * y^{6 *} x+g * x^{2} * y^{5}
\end{aligned}
$$

where $z=[\mathrm{R} / \mathrm{T}], x=\delta, y=\mathrm{pH}, a=-573.5, b=368.6$, $c=5272, d=-0.3134, e=0.02756, f=0.01535$ and $g=-0.4938$.

Also, have been analyzed how well it fits the experimental variables ( $\mathrm{pH}$ and $\delta$ ) in determining the values of the $[R / T]$ by the R-squared $R^{2}$ (equation 4 ), the sum of squared errors SSE (equation 5), and root mean square error RMSE (equation 6) The coefficient of determination is $R^{2}=0.99$ shows that $99 \%$ of the values of the $z$ are determined by the variables $x$ and $y$ :

$$
\begin{gathered}
R^{2}=1-\frac{\sum_{i=1}^{n}\left(y_{i}-f_{i}\right)^{2}}{\sum_{i=1}^{n}\left(y_{i}-\bar{y}\right)^{2}} \Leftrightarrow R^{2}=0.99 \\
S S E=\sum_{i=1}^{n} w_{i}\left(y_{i}-\hat{y}_{i}\right)^{2} \Leftrightarrow S S E=0.0329 \\
R M S E=\sqrt{\sum_{i=1}^{n} \frac{\left(\hat{y}_{i}-y_{i}\right)^{2}}{n}} \Leftrightarrow R M S E=0.1814
\end{gathered}
$$

By analyzing the correlation between $\mathrm{R} / \mathrm{T}$ and thickness $(\delta)$ and $\mathrm{pH}$, we observed that $\mathrm{R} / \mathrm{T}$ is an inverse proportionality relationship with the thickness (equation 7) and $\mathrm{pH}$ (equation 8), and this means that the reducing of the nickel layer thickness will generate a lower value for $\mathrm{R} / \mathrm{T}$ :

$$
\begin{gathered}
\text { Correlation }(R / T, p H)=\left|\begin{array}{cc}
1 & -0.24967 \\
-0.24967 & 1
\end{array}\right| \\
\text { Correlation }(R / T, \delta)=\left|\begin{array}{cc}
1 & -0.52347 \\
-0.52347 & 1
\end{array}\right|
\end{gathered}
$$

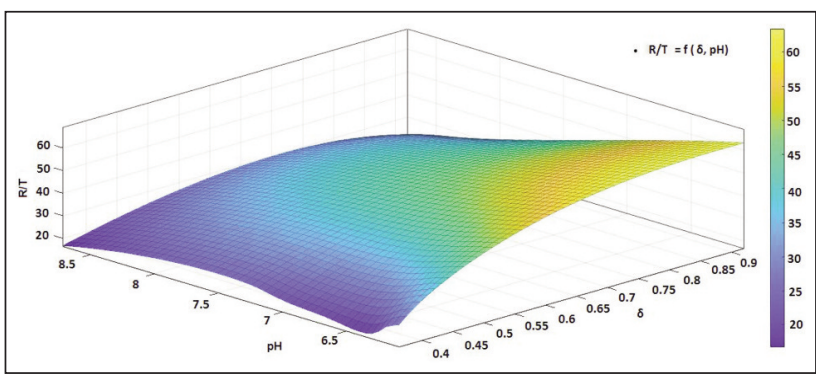

Fig. 4. 3D representation of the reflectance/transmittance $([\mathrm{R} / \mathrm{T}])$ according to the thickness $(\delta)$ and $\mathrm{pH}$

\section{CONCLUSIONS}

We can conclude that the experimental models 1-8 have specific values to insulating materials $\left(R_{s}>10^{12}\right.$ $\Omega$ ). Still, the solutions used for acid and alkaline sweat can influence the material effectiveness in reflecting radiant energy and efficiency in transmitting radiant energy. Besides, the surface resistivity and indirectly, the surface conductivity of the textile is influenced by acid/alkaline sweat treatments. Moreover, as a result of treatment with alkaline or acid sweat solutions, the surface resistance of the samples analyzed has been reduced, proving an excellent antistatic character $\left(10^{7}-10^{8} \Omega\right)$ and reflectance/transmittance increased. The transmittance and reflectance of the textile coated with a polymeric paste based on nickel are affected by the thickness [11-13] of the polymeric layer. Besides, the $\mathrm{pH}$ can influence the reflecting and transmitting radiation through the metallic layer deposited on the textile surface. A potential application of nickel printing, using both inks or paste, can be the developing of flexible composite electrodes [14-16].

Also, the correlation between $\mathrm{R} / \mathrm{T}$ and $\delta$, $\mathrm{pH}$ is harmful, and this means that the increase of the $\delta$ or $\mathrm{pH}$ values will generate the reduction of the $R / T$ values.

\section{ACKNOWLEDGMENTS}

The research presented in this paper was prepared in the INCDTP laboratories. Funds support this work from $\mathrm{MCl}$, National Project "Materiale textile compozite electroconductive pe bază de matrici polimerice $3 \mathrm{D}$ pentru sisteme senzoriale de monitorizare şi de atenuare a undelor electromagnetice (3D ELECTROTEX)", Contract PN 19170101.

\section{REFERENCES}

[1] Husson, F., Lê, S., Pagès, J., Exploratory multivariate analysis by example using R, , Chapman and hall/CRC, 2017

[2] Baker, M., European Standards Developed in Support of the European Union Nickel Directive, In: Metal Allergy, Springer Cham, 2018, 23-29

[3] Esmailzadeh, S., Aliofkhazraei, M., Sarlak, H., Interpretation of Cyclic Potentiodynamic Polarization Test Results for Study of Corrosion Behavior of Metals: A Review, In: Protection of Metals and Physical Chemistry of Surfaces, 2018, 54, 5, 976-989

[4] Moretti, G., Guidi, F., Tonini, R., Alloys at low nickel-release: Pd-Ni coatings on copper, In: Plating and surface finishing, 2001, 88, 4, 70-73

[5] Porcayo-Calderon, J., Rodríguez-Díaz, R.A., Porcayo-Palafox, E., Martinez-Gomez, L., Corrosion performance of Cu-based coins in artificial sweat, In: Journal of Chemistry, 2016 
[6] Hostynek, J.J., Maibach, H.I., Nickel and the skin: Absorption, immunology, epidemiology, and metallurgy, CRC Press, 2002

[7] Rovira, J., Nadal, M., Schuhmacher, M., Domingo, J.L., Trace elements in skin-contact clothes and migration to artificial sweat: risk assessment of human dermal exposure, In: Textile Research Journal, 2017, 87, 6, 726-738

[8] Rovira, J., Nadal, M., Schuhmacher, M., Domingo, J.L., Human exposure to trace elements through the skin by direct contact with clothing: risk assessment, In: Environmental research, 2015, 140, 308-316

[9] von Goetz, N., Lorenz, C., Windler, L., Nowack, B., Heuberger, M., Hungerbuhler, K., Migration of Ag-and $\mathrm{TiO}_{2}$-(Nano) particles from textiles into artificial sweat under physical stress: experiments and exposure modeling, In: Environmental science \& technology, 2013, 47, 17, 9979-9987

[10] Barel, A.O., Paye, M., Maibach, H.I., Handbook of cosmetic science and technology, CRC Press, 2014

[11] Sultan, M., Sultana, N., Analysis of reflectance and transmittance characteristics of optical thin film for various film materials, thicknesses and substrates, In: J. Electr. Electron. Sys., 2015, 4, 2332-0796

[12] McKnight, S.W., Stewart, K.P., Drew, H.D., Moorjani, K., Wavelength-independent anti-interference coating for the far-infrared, In: Infrared physics, 1987, 27, 5, 327-333

[13] Akman, O., Kavas, H., Baykal, A., Toprak, M.S., Çoruh, A., Aktaş, B., Magnetic metal nanoparticles coated polyacrylonitrile textiles as microwave absorber, In: Journal of Magnetism and Magnetic Materials, 2013, 327, $151-158$

[14] Zheng, Z., Casey, Y.A.N., Lau, L.C., EPRO DEVELOPMENT Ltd, Electrically conductive textile element and method of producing same, U.S. Patent Application 16/593,885, 2020

[15] Hayashi, A., Yamazaki, T., Kinoe, K., Riso Kagaku Corp, Ink for inkjet textile printing, ink set, and method for producing printed item, U.S. Patent Application 16/454,669, 2020

[16] Meng, X., Wang, Z., Di Benedetto, G., Zunino III, J.L., Mitra, S., Development of printable, flexible nickel-iron batteries based on composite electrodes, In: Energy Storage, 2020, 2, 1, 105

\section{Authors:}

RALUCA MARIA AILENI, LAURA CHIRIAC, SILVIA ALBICI, IRINA-MARIANA SANDULACHE, VALERIA NEAGU, LILIANA RADUCU

National Research and Development Institute for Textiles and Leather, Lucretiu Patrascanu Street, no.16, 030508, Bucharest, Romania

Corresponding author:

RALUCA MARIA AILENI

e-mail: raluca.aileni@incdtp.ro 